\title{
An unusually rapid Claisen rearrangement involving ring expansion
}

\author{
Gianluca Dimartino and Jonathan M. Percy* \\ School of Chemistry, University of Birmingham, Edgbaston, Birmingham, UK B15 2TT. \\ E-mail: jmpercy@chemistry.bham.ac.uk
}

\section{Received (in Cambridge, UK) 18th September 2000, Accepted 23rd October 2000} First published as an Advance Article on the web 10th November 2000

\begin{abstract}
A Claisen rearrangement of a partially-fluorinated system involving ring expansion occurred at an unusually low temperature, $100{ }^{\circ} \mathrm{C}$ lower than a comparable system from the literature.
\end{abstract}

Paquette and co-workers showed how the Claisen rearrangement could be used to transform readily available vinylic lactones into medium-ring carbocycles during a series of landmark natural product syntheses. ${ }^{1}$ The Tebbe reaction ${ }^{2}$ fulfils a critical role in providing the vinyl ether component of the allyl vinyl rearrangement precursor; Scheme 1 summarises the sequence.

The rearrangement step requires the use of high temperatures and some special experimental precautions $;^{3}$ after the Tebbe reaction, the allyl vinyl ether is sealed in base washed tubes to minimise decomposition through enol ether protiolysis and Paquette notes that following minimal enol ether purification, traces of the Tebbe reagent by-products may be present in the rearrangement medium. Given that aluminium reagents are indeed known to cause dramatic accelerations of [3,3]-Claisen rearrangements ${ }^{4}$ some assistance to the rearrangement would not be surprising, though the nature of the active Lewis acid is not clear nor is the effect large given the reaction conditions (23 $\mathrm{h}$ at $175{ }^{\circ} \mathrm{C}$ in Scheme 1). Double bond migration can also compete with rearrangement forming non-productive allyl vinyl ethers.

We were interested to see if halogenation of the allylic fragment would accelerate the ring expansion and lower the reaction temperature. The literature suggests that $\gamma, \gamma$-difluorination accelerates [3,3]-Claisen rearrangements in some cases; ${ }^{5}$ though the idea has not been tested fully and definitive theoretical work does not exist, a general concensus exists that the rehybridisation of an $\mathrm{sp}^{2} \mathrm{CF}_{2}$ centre to $\mathrm{sp}^{3}$ is favoured as geminal $\mathrm{CF}_{2}$-substitution destabilises the alkene. Unambiguous accelerative effects exerted in $\gamma, \gamma$-difluorinated systems have also been reported in other rearrangement systems including $[2,3]$-Wittigs, ${ }^{6}$ heteroatomic [2,3]-rearrangements ${ }^{7}$ and oxyCope $^{8}$ reactions.

Stork enamine chemistry allowed the syntheses of ketoesters $\mathbf{2 a}$ and $\mathbf{2 b}$ and the addition of 1-chloro-2,2-difluoroethenyllithium ${ }^{9}$ generated from 1-chloro-2,2,2-trifluoroethane afforded good yields of alcohol products $\mathbf{3 a}$ as a mixture of diastereoisomers (Scheme 2); we assume that the major product has a trans-relationship between the sidechains. ${ }^{3}$

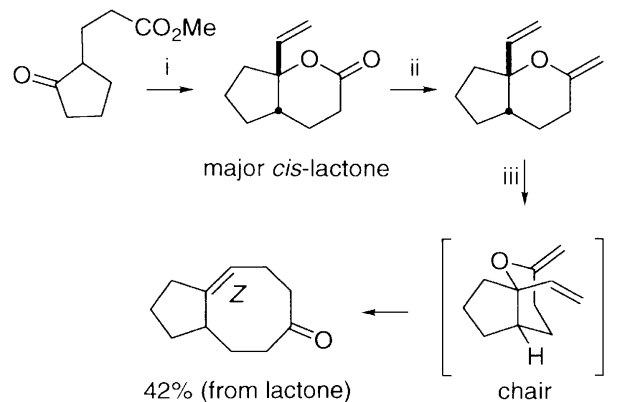

Scheme 1 Reagents and conditions: i, vinylmagnesium bromide; ii, $\mathrm{Cp}_{2} \mathrm{TiCl}\left(\mathrm{CH}_{2}\right) \mathrm{AlMe}_{3}$ (Tebbe reagent); iii, $175^{\circ} \mathrm{C}, 23 \mathrm{~h}$.

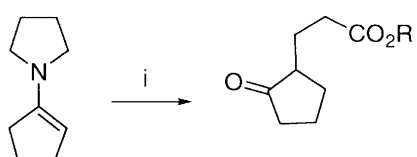

2a, $\mathrm{R}=\mathrm{Et}(81 \%)$ $2 \mathrm{~b}, \mathrm{R}=t-\mathrm{Bu}(72 \%)$

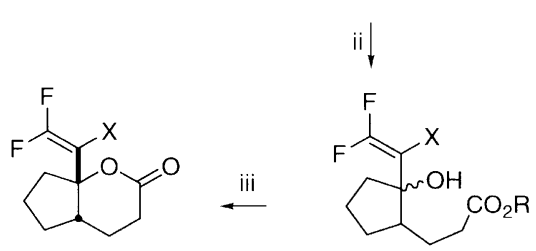

4a, $\mathrm{X}=\mathrm{Cl}(52 \%)$ 4b, $X=F(60 \%)$

3a, $\mathrm{R}=\mathrm{Et} ; \mathrm{X}=\mathrm{Cl}(70 \%)$

3b, $R=E t ; X=F(75 \%)$

3c, $\mathrm{R}=t-\mathrm{Bu}, \mathrm{X}=\mathrm{Cl}(63 \%)$

3d, $R=t-B u, X=F(80 \%)$

Scheme 2 Reagents and conditions: i, ethyl acrylate or tert-butyl acrylate, dioxane, rt, $18 \mathrm{~h}$; ii, 1-chloro-2,2-difluoroethenyllithium or 1,2,2-trifluoroethenyllithium, THF, $-78^{\circ} \mathrm{C}$ to $\mathrm{rt}$; iii, $\mathrm{CF}_{3} \mathrm{CO}_{2} \mathrm{H}$, THF, rt.

No lactone products were detected; what we expected was the collapse of the initial alkoxide onto the ester in at least one of the diastereoisomers. After isolating the hydroxyester, we tried to lactonise it under acidic and basic conditions but failed. Instead of hydrolysing the acid, we synthesised tert-butyl ester $\mathbf{3 c}$ as a mixture of diastereoisomers; a single lactone, to which we assigned structure $\mathbf{4 a}$, was isolated in moderate yield after treatment of these hydroxyesters with trifluoroacetic acid in dichloromethane. Presumably, alkyl-O cleavage and carboxy protonation allows closure to the lactone; it seems less likely that the acid intercepts an allylic cation generated by protonation of, and departure of water from, the hydroxyacid. A similar successful sequence started from 1,2,2,2-tetrafluoroethane (HFC-134a) and afforded lactone 4b. ${ }^{10}$

With the lactone in hand, we attempted the Tebbe reaction $\dagger$ (Scheme 3) and succeeded in transforming lactone $\mathbf{4 a}$ completely to a new product as evinced by ${ }^{19} \mathrm{~F}$ NMR, to which we assign structure $\mathbf{5}$
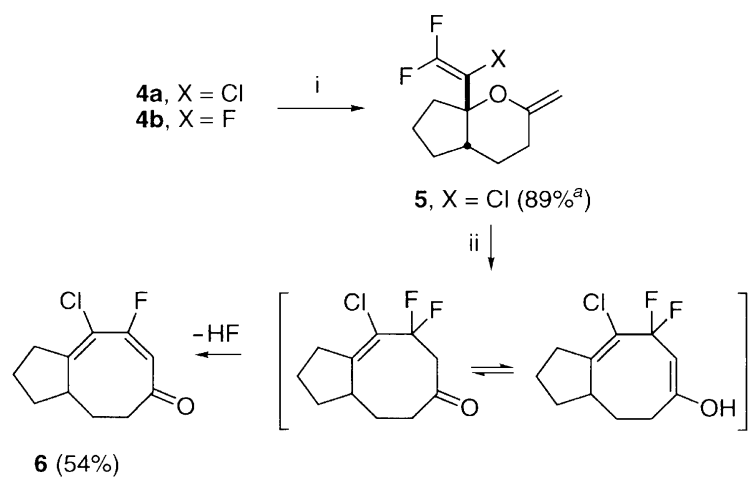

Scheme 3 Reagents and conditions: i, $\mathrm{Cp} 2 \mathrm{TiCl}\left(\mathrm{CH}_{2}\right) \mathrm{AlMe}_{3}, \mathrm{PhMe}-\mathrm{THF}, 0$ to $60{ }^{\circ} \mathrm{C}$; ii, xylene, sealed base-washed tube, $85^{\circ} \mathrm{C}, 4$ h. ${ }^{a}$ Estimated yield based on clean ${ }^{19} \mathrm{~F}$ NMR and full conversion of $\mathbf{4 a}$ 
In contrast, the fluorinated congener $\mathbf{4 b}$ decomposed completely under Tebbe conditions. All attempts to purify and rigorously characterise $\mathbf{5}$ resulted in decomposition so we simply heated $\mathbf{5}$ at $85{ }^{\circ} \mathrm{C}$; complete consumption took place within $4 \mathrm{~h}$ and a new UV active product 6 was formed. $\neq$ The rearrangement conditions contrast sharply with those in Scheme 1. We contend that this represents an unusually facile [3,3]-Claisen ring expansion; as the Claisen rearrangement is not usually reversible, it is hard to see how dehydrofluorination after the rearrangement could accelerate the rearrangement itself. Enol formation from the initial ketonic product followed by elimination of $\mathrm{HF}$ does result in the formation of a conjugated system so dienone formation is not surprising.

We are currently in pursuit of $\mathbf{7}$ in which the fluorine atoms

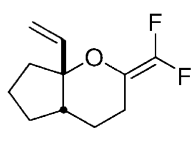

7

are in the vinyl component of the Claisen precursor, so that we can compare the positional effects of fluorine atom substitution and retain both fluorine atoms in a structurally novel product.

In summary, we have shown that the rearrangement precursor can be assembled rapidly, that the fluoroallyl fragment survives Tebbe reaction conditions and that fluorine atoms at $\mathrm{C}-\gamma$ in the allyl fragment appear to lower considerably the barrier to ring expansion Claisen rearrangement.

The authors wish to thank the Engineering and Physical Sciences Research Council of Great Britain for a Project Studentship (to G. D.) under the ROPA Scheme and ICI Klea for a generous donation of HFC-134a.

\section{Notes and references}

$\dagger$ Tebbe procedure and ${ }^{19} \mathrm{~F}$ NMR data for 5: Tebbe reagent $(2.2 \mathrm{ml}$ of a 0.5 $\mathrm{M}$ solution in toluene, $1.1 \mathrm{mmol}$ ) was added to a stirred solution of lactone 4a $(0.236 \mathrm{~g}, 1.0 \mathrm{mmol})$ in dry THF $(10 \mathrm{ml})$ at $0{ }^{\circ} \mathrm{C}$. Fifteen min after the addition the mixture was allowed to warm to $\mathrm{rt}$ and stirred for a further 20 min. The mixture was then heated to $60{ }^{\circ} \mathrm{C}$ for $30 \mathrm{~min}$, then cooled to $0{ }^{\circ} \mathrm{C}$ before being quenched with $15 \% \mathrm{NaOH}$ solution $(5 \mathrm{ml})$. After gas evolution had ceased, ether $(10 \mathrm{ml})$ was added and the mixture was dried, filtered and evaporated. The residue was eluted through a short column of alumina with petroleum ether to provide $5(0.20 \mathrm{~g}, 89 \%$ estimated) as the only fluorinecontaining product: $\delta_{\mathrm{F}}\left(282 \mathrm{MHz}, \mathrm{CDCl}_{3}\right)-81.8\left(\mathrm{~d},{ }^{2} J_{\mathrm{F}-\mathrm{F}} 38.7,1 \mathrm{~F}\right),-84.9$ $\left(\mathrm{d},{ }^{2} J_{\mathrm{F}-\mathrm{F}} 38.7,1 \mathrm{~F}\right)$. As 5 was expected to be unstable, it was taken on directly without further purification.

\$ Thermal rearrangement and selected data for $\mathbf{6 : 5}(0.234 \mathrm{~g}, 1.0 \mathrm{mmol})$ was dissolved in xylene $(5 \mathrm{ml})$ in an Ace tube that had been washed with $\mathrm{NaOH}$ (5 $\mathrm{M}$ aqueous solution). The tube was then sealed and heated to $85{ }^{\circ} \mathrm{C}$ in an oil bath. The reaction was followed by ${ }^{19} \mathrm{~F}$ NMR of aliquots until the starting material was consumed completely $(4 \mathrm{~h})$. Concentration and purification via silica gel column chromatography (10\% ether in light petroleum) gave $\mathbf{6}$ $(0.116 \mathrm{~g}, 54 \%)$ as a yellow oil; $R_{\mathrm{f}}(10 \%$ ether in light petroleum) $0.2(95 \%$ by GC); $\delta_{\mathrm{H}}\left(300 \mathrm{MHz}, \mathrm{CDCl}_{3}\right) 5.87\left(\mathrm{~d},{ }^{3} J_{\mathrm{H}-\mathrm{F}} 20.2,1 \mathrm{H}\right), 3.03-2.88(\mathrm{~m}, 1 \mathrm{H})$, $2.87-2.53(\mathrm{~m}, 2 \mathrm{H}), 2.42-2.30(\mathrm{~m}, 1 \mathrm{H}), 2.20-2.02(\mathrm{~m}, 1 \mathrm{H}), 1.98-1.05(\mathrm{~m}$, $6 \mathrm{H}) ; \delta_{\mathrm{F}}\left(282 \mathrm{MHz}, \mathrm{CDCl}_{3}\right)-83.9\left(\mathrm{~d},{ }^{2} J_{\mathrm{F}-\mathrm{H}} 20.0\right) ; v_{\max }(\mathrm{film}) / \mathrm{cm}^{-1} 1662$, 1627; [HRMS (CI, M[NH ${ }_{4}^{+}$]) Found: 232.0912. Calc. For $\mathrm{C}_{11} \mathrm{H}_{16} \mathrm{ClFNO}$ : 232.0905]; $\mathrm{m} / z(\mathrm{CI}) 232\left(\mathrm{M}+\mathrm{NH}_{4}+\right), 215\left(\mathrm{M}+\mathrm{H}^{+}\right) ; \lambda_{\max }\left(\mathrm{CH}_{2} \mathrm{Cl}_{2}\right) 284 \mathrm{~nm}(\varepsilon$ $\left.3600 \mathrm{dm}^{3} \mathrm{~mol}^{-1} \mathrm{~cm}^{-1}\right){ }^{11}$

1 For a recent example, see L. A. Paquette, J. Ezquerra and W. He, J. Org. Chem., 1995, 60, 1435.

2 F. N. Tebbe, G. W. Parshall and G. S. Reddy, J. Am. Chem. Soc., 1978, 100, 3611 .

3 W. A. Kinney, M. J. Coghlan and L. A. Paquette, J. Am. Chem. Soc., 1985, 107, 7352.

4 H. Yamamoto, in Organometallics in Synthesis: A Manual, ed. M. Schlosser, Wiley, Chichester, 1994, 509. For a recent boron Lewis acid catalysed example involving a fluorinated allyl vinyl ether, see H. Ito, A. Sato, T. Kobayashi and T. Taguchi, Chem. Commun., 1998, 2441.

5 S. T. Purrington and S. C. Weeks, J. Fluorine Chem., 1992, 56, 165; J. M. Percy, Top. Curr. Chem., 1997, 193, 131; J. M. Percy and M. E. Prime, J. Fluorine Chem., 1999, 100, 147. For a discussion relating specifically to Claisen rearrangements, see M. J. Broadhurst, S. J. Brown, J. M. Percy and M. E. Prime, J. Chem. Soc., Perkin Trans. 1, 2000, 3217.

6 S. T. Patel, J. M. Percy and R. D. Wilkes, J. Org. Chem., 1996, 61, 166.

7 K. Blades, S. T. Patel, J. M. Percy and R. D. Wilkes, Tetrahedron Lett., 1996, 37, 6403.

8 G. Dimartino, T. Gelbrich, M. B. Hursthouse, M. E. Light, J. M. Percy and N. S. Spencer, Chem. Commun., 1999, 2535.

9 J. M. Bainbridge, S. J. Brown, P. N. Ewing, R. R. Gibson and J. M. Percy, J. Chem. Soc., Perkin Trans. 1, 1998, 2541. The same method was used to prepare the trifluorovinyl congeners from HFC-134a. See also P. L. Coe, J. Burdon and I. B. Haslock, J. Fluorine Chem., 2000, 102, 43 .

10 In this case alone, the two diastereoisomers of $\mathbf{3 d}$ could be separated. Only one of them lactonised (TFA in $\mathrm{CH}_{2} \mathrm{Cl}_{2}$ ) while the other decomposed completely.

11 The only similar compound we were able to find with reported UV data was 1-ethoxycarbonyl-5-oxo-1,3-cyclooctadiene $\left[\lambda_{\max }(95 \% \mathrm{EtOH})\right.$ $282 \mathrm{~nm}\left(\varepsilon 9700 \mathrm{dm}^{3} \mathrm{~mol}^{-1} \mathrm{~cm}^{-1}\right.$ ]: see W. C. Agosta and W. W. Lowrance, J. Org. Chem., 1970, 35, 3851. 